Ingrid Helleve

Universitetet i Bergen

Marit Ulvik

Universitetet i Bergen

Kari Smith

Norges teknisk-naturvitenskapelige universitet

DOI: http://dx.doi.org/10.5617/adno.4794

\title{
«Det handler om å finne sin egen form» Læreres profesjonelle handlingsrom - hvordan det blir forstått og utnyttet
}

\section{Sammendrag}

Målet med denne studien er å undersøke hvordan lcerere forstår og tolker sitt profesjonelle handlingsrom og hvordan de, basert på denne erfaringen, har opplevd å nå sine egne mål over tid. Studien, som er del av en internasjonal studie, bygger på observasjoner, intervjuer og story-lines fra seks læerere ved tre videregående skoler. Lcererne er av ledelsen utpekt til å være larere som utnytter det handlingsrommet de har og som selv tar styring på hvordan de praktiserer lererjobben. Funnene viser at leererne langt på vei tolker og endrer rammer og regelverk i tråd med egne mål - også lcerere innenfor samme kontekst. De fleste larerne opplever at de utnytter og har utnyttet et større handlingsrom enn de erfarer å ha med bakgrunn i rammer og pålegg. Dette resultatet skiller seg fra de to andre landene som deltar i den internasjonale studien. Konklusjonen er at kunnskap om lcereres forståelse av sitt profesjonelle handlingsrom kan bidra til refleksjon over egen lcererrolle og til ny innsikt i skoleutvikling.

Nøkkelord: profesjonelt handlingsrom, videregående skole, lcerere

\section{Teachers' professional space - How it is experienced and utilized}

\begin{abstract}
The aim of the study is to examine teachers' understanding and interpretation of their professional space, and how they experience having possibilities to practice their pedagogical beliefs throughout their careers. The study, which is part of an international study, is built on observations, interviews and storylines from six teachers in three Norwegian upper secondary schools. These are
\end{abstract}


teachers viewed by their principals as independent teachers exploiting their professional space when practicing teaching. Findings show that to a large extent teachers interpret and change frames and rules according to their own pedagogical beliefs. Teachers working in the same schools respond differently to school regulations. Most of the teachers claim to have more space than what they perceive external rules and frameworks allow for. This finding differs from the two other participating countries in the international study, in which obedience to external regulations was strong. The conclusion reached in this paper is that additional knowledge about teachers' perceptions of their professional space will contribute to ways in which reflection of practice and professional role can be enhanced, and thereby support school development.

Keywords: professional space, upper secondary school, teachers

\section{Innledning}

Læreres utnyttelse av sitt profesjonelle handlingsrom viser seg å ha stor betydning for å forstå hvilke prosesser som ligger til grunn for elevers læring og for skoleutvikling (Toom, Pyhältö \& O’Connell Rust, 2015; Van der Heijden, Geldens, Beijaard \& Popeijus, 2015). Utviklingen de siste tiårene har vært preget av en utdanningspolitikk som kan karakteriseres som en epidemi av forandringer (Priestley, Edwards \& Priestley, 2012). Lærere opplever en stadig økende arbeidsmengde i form av krav til måloppnåelse, papirarbeid og byråkrati (Ball, 2008; Hargreaves \& Goodson, 2006; Skaalvik \& Skaalvik, 2010). Det er i dette terrenget at læreres erfaringer med og utnyttelse av sitt profesjonelle handlingsrom får økende oppmerksomhet ifølge flere forskere (Buchanan, 2015; Priestley, Biesta, Phillippou \& Robinson, 2015). Sett utenfra kan rammefaktorer og regler oppfattes som objektive størrelser som alle i en organisasjon retter seg etter. Sett innenfra vil de samme påleggene oppfattes og tolkes ulikt. Mennesker er ikke maskiner som kan programmeres. Krav til standarder og måloppnåelse forståes ulikt av ulike aktører. Lærere er ledere av læringsfellesskap. De tar sine egne valg og beslutninger innenfor det de opplever som sitt rom for handling. Dette rommet finnes ikke fysisk og kan ikke måles. Det er definert av lærerens egen opplevelse av situasjonen.

Det vi ønsker å fokusere på i denne studien, er forholdet mellom det handlingsrommet lærere erfarer at de har, et rom som er regulert av rammer og pålegg, og det rommet de selv opplever at de er i stand til å utnytte profesjonelt. Rammer forstås både som uttrykte krav og forventninger og som usagte normer i skolekulturen. Utgangspunktet for denne artikkelen er et internasjonalt prosjekt om læreres profesjonelle handlingsrom i tre land, Israel, Nederland og Norge (Oolbekkink-Marchand, Hadar, Smith, Helleve \& Ulvik, 2017). 
Så langt finnes det lite empiri på læreres egen opplevelse av handlingsrom (Oolbekkink-Marchand et al., 2017). Svaret på hvordan de erfarer handlingsrommet, kan gi oss innsikt i hvordan de er i stand til å ta kontroll over sin egen praksis og til å styre ut fra egne mål. Vi valgte i denne studien en positiv vinkling og ville se på mulighetene lærere opplever på tross av økende krav fra ytre aktører (Ball, 2008; Hargreaves \& Goodson, 2006; Skaalvik \& Skaalvik, 2010; Utdanningsforbundet, 2014). Vi har derfor undersøkt det som kan antas å være positive case. Utvalget av informanter er derfor gjort blant lærere som av skolens ledelse ble vurdert til å være lærere som utnytter det handlingsrommet de har, og som selv tar styring på hvordan de praktiserer lærerjobben.

Målet med artikkelen er å få en dypere forståelse av hvordan lærere selv opplever at de utnytter og har utnyttet sitt profesjonelle handlingsrom når de ser tilbake på yrkeskarrieren sin. $\AA$ være en profesjonell lærer betyr i denne sammenhengen å ha dyp kunnskap i faget og om undervisning $\mathrm{i}$ faget, ha forståelse av egne holdninger som styrer praksis, samt å kunne finne og anvende kunnskap som passer for elevene. Videre betyr det å ha et konstant søkelys (monitoring) på hvordan egen praksis påvirker elevene og dessuten å søke kunnskap for å endre det som fungerer mindre bra (Hammerness, DarlingHammond \& Bransford, 2005).

Problemstillingen er todelt:

1. Hvilket profesjonelt handlingsrom erfarer lærerne at de har, og i hvilken grad opplever de at de utnytter handlingsrommet?

2. Hvordan har opplevelsen av erfart handlingsrom og muligheter for eventuelt å utnytte dette handlingsrommet endret seg i løpet av yrkeskarrieren?

\section{Handlingsrom og agency}

Forståelsen av begrepet profesjonelt handlingsrom er knyttet til et annet begrep, agency, som brukes i den engelskspråklige studien som denne studien er en del av (Oolbekkink-Marchand et al., 2017). Dette begrepet er vanskelig å oversette til norsk. I denne studien velger vi å bruke begrepet profesjonelt handlingsrom. I det følgende vil vi forklare hvordan vi forstår begrepene agency og profesjonelt handlingsrom og hvordan de relateres til hverandre.

Begrepet agency bygger på at mennesket handler intensjonalt, det vil si i tråd med egne mål. Dette skjer gjennom personlige tolkninger og tilpasninger av rammevilkårene i interaksjon med omgivelsene. Begrepet er knyttet til det å være agent, en som bidrar til livsvilkårene, ikke bare er et produkt av dem (Bandura, 2006), og vil i denne sammenhengen inkludere vilje, autonomi, frihet og valg (Biesta \& Tedder, 2007; Erimbayer \& Mische, 1998; Priestley et al., 2015). Agency kan derfor forståes som kapasiteten den enkelte har til å gjen- 
nomføre en målrettet handling. Det vil si å handle i tråd med sin profesjonelle forståelse og egne mål. Så langt har vi beskrevet agency som en individuell egenskap, men mennesker lever ikke i vakuum; de utgjør hverandres omgivelser (Bandura, 2006). Mulighetene for å utøve agency vil variere med vilkårene omgivelsene gir for påvirkning og interaksjon. Bandura (2006) beskriver også betydningen av kollektivet. En artikkel av Erimbayer og Mische (1998) som ofte blir vist til, har følgende definisjon på agency:

midlertidig konstruert engasjement av aktører i ulike strukturerte miljø - den midlertidig relasjonelle handlingskonteksten - som gjennom samspill med vaner, fantasi og dømmekraft både reproduserer og transformerer disse strukturene i interaktiv respons med utfordringene som oppstår i nye historiske situasjoner (s. 970, forfatternes oversettelse)

Overført til læreryrket vil det si at agency uttrykker læreres evne til å handle utover kontekstuelle regler og reguleringer og omgjøre disse slik at de handler i samsvar med sin profesjonelle forståelse og sine egne mål innenfor det vi definerer som lærerens profesjonelle handlingsrom.

Lærerne skaper dette handlingsrommet der de forsøker å nå egne profesjonelle mål basert på evner og kontekstuelle muligheter. Lærernes opplevelse av handlingsrom og utøvelse av agency er påvirket av tidligere erfaringer, nåværende kontekst og planer for framtiden. Derfor vil agency være dynamisk og endre seg når konteksten endrer seg (Biesta \& Tedder, 2007). Opplevelsen av handlingsrom begrenses av ytre rammer fastsatt av myndighetene og indre grenser som er mer epistemiske og er knyttet til kunnskaps- og verdisyn (Berg \& Wallin, 1983; Jeppesen, Kelder \& Ottesen, 2016). Det vil si at handlingsrommet avhenger av ytre pålegg, av kunnskaper og ferdigheter lærerne bringer med seg, men også av deres antagelser og verdier (Biesta, Priestley \& Robinson, 2015). I vår studie har vi kalt den subjektive opplevelsen av begrensninger og muligheter basert på rammefaktorer «erfart handlingsrom». Læreres egen forståelse av hvor yttergrensen for utnyttelse av handlingsrommet går, har vi valgt å kalle «utnyttet handlingsrom». Innenfor disse grensene arbeider lærerne mot sine mål innenfor sitt egendefinerte profesjonelle handlingsrom. Det er lærerens opplevelse av de ytre rammene og av mulighetene for å utnytte handlingsrommet for å nå egne profesjonelle mål, vi vil undersøke i denne studien.

\section{Profesjonelt handlingsrom}

Lærere har, som andre arbeidstakere, en jobb som er styrt av objektive rammefaktorer som for eksempel politiske lover og læreplaner. Videre har hver skole sine regler, rutiner og uskrevne normer som alle er forventet å følge (Jeppesen et al., 2016). Rammene angir de objektive målene. Innenfor rammen av vedtatte forordninger har læreren sitt profesjonelle handlingsrom. Ellström, Ekholm og 
Ellström (2007) viser at lærere aktivt tolker skolekonteksten og handler ut fra egne mål. Forskning viser også at opplevelsen av muligheter eller begrensninger i handlingsrommet kan ha større innflytelse på lærerens handlinger enn de objektive rammefaktorene (Hoekstra, Korthagen, Brekelmans, Beijaard \& Imants, 2009). Målene den enkelte lærer handler ut fra, trenger ikke å være de samme som de resten av organisasjonen arbeider mot (Imants, Wubbels \& Vermunt, 2013).

Når det gjelder skoleledelse, viser forskning innenfor den nasjonale konteksten at norske skoleledere i liten grad legger seg opp i lærernes pedagogiske arbeid og tilrettelegging av undervisning. Norske rektorer er i liten grad opptatt av å kontrollere eller detaljstyre det som skjer i klasserommene, noe som blir beskrevet som den skjulte kontrakten mellom skolelederen og lærerne med tanke på arbeidsdeling, makt og innflytelse. Lærere og ledere har ansvar for sine domener og lar hverandre være i fred (Møller, 2004, 2006; Hovdelien, 2010).

Studier viser også at lærere innenfor samme skolekontekst kan respondere forskjellig på ytre rammer og handle ulikt basert på ulike tolkninger av eget handlingsrom. Studien til Imants m.fl. (2013) viser hvordan de samme arbeidsplassforholdene gir muligheter for noen lærere og virker hemmende på andre. Læreres definisjoner av og holdninger til reformer er basert på personlige oppfatninger og tolkninger.

En studie gjennomført av Priestley, Edwards og Priestley (2012) viser også hvordan lærere i to like kontekster kan handle helt forskjellig. Graden av opplevelse av handlingsrom varierer innenfor samme skole basert på miljømessig opplevelse av muligheter og motstand. Viktige påvirkningsfaktorer ligger i tro, verdier og holdninger som lærere mobiliserer i situasjonen. Men opplevelsen av muligheter for å handle i tråd med egne mål vil også avhenge av erfaring. Buchanan (2015) har fulgt nye lærere for å se hvordan de konstruerer sin læreridentitet i en periode preget av målstyring i utdanningssystemet. Hun forklarer læreres opplevelse av handlingsrom som profesjonell identitet i bevegelse. Handlingsrom er for lærerne i hennes studie forbundet med å kunne undervise i tråd med sine idealer gjennom å være den læreren man ønsker å være. Studien viser at nye lærere lett gir opp sine idealer og tilpasser seg ytre rammer og mål (Rippon \& Martin, 2006; Grudnoff, 2012). Konklusjonen er at nye lærere som starter sin yrkeskarriere i en tid preget av krav til resultater og dokumentasjon, ser ut til å tilpasse seg lettere til mål satt av andre enn de som har lengre erfaring.

Flere forskere peker på at det som ser ut til å bety mest for lærere, er elevers læring i klasserommet. Biesta, Priestley og Robinson (2015) har undersøkt hvordan reformer blir forstått og gjennomført, og hvilken rolle «tro» spiller i læreres tolkning og utnyttelse av handlingsrom. Funnene viser at lærere i stor grad handler i tråd med det de tror på i pedagogisk sammenheng. Hovedkonklusjonen er at lærernes sterke engasjement i elevers læring gir dem en sterk stemme i utformingen av skolepolitikken. Måten lærere utnytter handlingsrom- 
met på, vil avhenge av den innsikten og forståelsen de har av sitt profesjonelle handlingsrom (Biesta, Priestley \& Robinson, 2015).

Ballet, Kelchtermans og Loughran (2006) peker også på at det alltid finnes rom for tolking og forhandling og at lærere filtrerer endringer gjennom sine personlige standarder. Særlig vil elvenes beste være avgjørende for hvor lydige lærere er mot ytre bestemmelser. Forskerne peker imidlertid på at samarbeidskultur og god ledelse kan fungere som buffere mot eksterne krav lærere ikke ser verdien av. Manglende innflytelse blir nevnt som en stressfremmende faktor.

I følge Priestley m.fl. (2015) er det viktig å utforske læreres opplevelse av handlingsrom for å få en dypere forståelse av lærerprofesjonalitet og skolens indre liv med tanke på skoleutvikling. Lærere blir ofte framstilt som endringsagenter. Parallelt hevdes det fra politisk hold at lærere trenger mer utdanning, samtidig som den samme yrkesgruppen blir utsatt for stadig økende press med tanke på standardisering og målbare resultater. De tre budskapene er motstridende, og gir uklare signaler med tanke på utvikling innenfra eller utenfra organisasjonen. De motstridende signalene kan tyde på at politikere ikke forstår de indre mekanismene i skolenes liv. Lærere finner sitt profesjonelle handlingsrom gjennom aktiv og kontinuerlig evaluering av omgivelsenes rammer og gjennom å interagere innenfor disse rammene. Samtidig viser studier at lærere i liten grad opplever å delta i visjoner og planer for skole og utdanning utover sin egen kontekst (Pyhältö, Pietarinen \& Soini, 2012).

Den siste studien vi vil vise til, er den internasjonale studien som denne studien er en del av, og som bygger på empiri fra til sammen 18 narrativer fra Israel, Nederland og Norge med seks case-studier fra hvert land (OolbekkinkMarchand et al., 2017). Det er den norske delen av studien som blir beskrevet og drøftet i denne artikkelen. Målet med den internasjonale studien er å få mer innsikt i læreres opplevelse av profesjonelt handlingsrom. Funnene viser at forståelsen av erfart og utnyttet handlingsrom endrer seg over tid, påvirket av personlige og kontekstuelle faktorer. De fleste lærerne opplevde en økende grad av erfart, så vel som utnyttet handlingsrom gjennom yrkeslivet. Videre viser lærerne til viktige hendelser som har fått konsekvenser for opplevelsen og utnyttelsen av handlingsrommet. Et siste funn handler om sammenligningen mellom de tre landene som viser at norske lærere i større grad enn i de andre landene opplever at de utnytter et større handlingsrom enn de erfarer å ha. Dette kommer vi tilbake til når vi løfter fram funn fra vår studie.

\section{Kontekst og utvalg}

Den komparative artikkelen som denne studien er en del av (OolbekkinkMarchand et al., 2017) hadde en tverrnasjonal analyse av data. I denne artikkelen er det kun det norske utvalget på seks lærere som inngår. Empirien har gjennomgått en ny vertikal så vel som horisontal analyse for å få en dypere for- 
ståelse av og relevans for vår egen nasjonale kontekst. Den vertikale analysen ga en dypere forståelse av hver enkelt case. Gjennom den horisontale analysen fikk vi en bedre forståelse av likheter mellom de ulike casene. Den norske delstudien er utført i tre videregående skoler. Kravet var at lærerne skulle ha mer enn fem års erfaring i yrket, og dessuten fast jobb. Utvalget består av lærere med ulike fagkombinasjoner fra forskjellige program. Videregående skole skiller seg fra grunnskolen ved at lærerne i større grad er faglærere. De har et sterkere resultatpress, ikke minst fra elevenes side.

En del av avtalen vi som forskere inngikk med de andre internasjonale forskerne, var at vi skulle rekruttere informanter gjennom skoleledelsen. For å få tilgang til feltet tok vi kontakt med rektorer vi hadde tillit til på tre videregående skoler og ba dem kontakte to lærere som de opplevde var i stand til å utnytte det handlingsrommet de hadde, og til selv å ta styring på hvordan de praktiserte jobben. I ettertid kontaktet vi rektorene for å få vite hvordan de hadde forstått oppdraget. Svarene var at de hadde spurt lærere som var samvittighetsfulle og så ut til å trives i jobben som de utførte på en utmerket måte. Lærerne var, ifølge rektorene, ikke nødvendigvis enige med det nye byråkratiet, men var opptatt av at elevene skulle lære mest mulig og at de skulle prestere bra på eksamen. Seks lærere, to fra hver skole, fikk spørsmål om å delta i prosjektet og tok deretter kontakt med oss som forskere. Alle lærere rektorene hadde anbefalt, ønsket å delta.

Skole A har ca. 1000 elever. Mari og Ole jobber der. Mari underviser i samfunnsfag, geografi og religion i mange klasser. Hun har vært lærer i 9 år. Tidligere jobbet hun på en liten, videregående skole og før det igjen i barneskolen. Ole underviser i fagene norsk og tysk. Han har 26 års erfaring som lærer. Han har vært tillitsvalgt, også på nasjonalt nivå, og er opptatt av utdanningspolitikk. I studietiden var han engasjert i studentpolitikk. De fleste årene har han vært på samme skole, men har to ganger opplevd at skolen han jobbet på ble fusjonert. Han er kontaktlærer for en førsteklasse, men underviser også avgangselever og trives svært godt med det. Bitte og Tom er lærere på videregående skole B, en skole med ca. 400 elever. Skolen, som ligger i et tettsted, er gammel med lange tradisjoner. Bitte underviser i samfunnsfag, spansk og religion. Hun underviste først på en barne- og ungdomsskole. Deretter var hun flere år i privat næringsliv før hun ble ansatt på en ren ungdomsskole. Hun har vært på skole B i åtte år og er svært fornøyd med å være lærer i videregående skole. Tom underviser i fagene naturfag og matematikk. Han har jobbet i 15 år. De første fem årene var han lærer på nettstudier, og de siste ti årene har han vært på denne skolen. Han underviser på Vg1 og i idrettsklasser. Skole C ligger også i et tettsted og har ca. 1000 elever. Knut har vært lærer i 16 år og har vært på samme skole hele tiden. Han er norsklærer på studiespesialiserende linje. Per har vært ved denne skolen i 27 år. Til sammen har han vært lærer i 36 år. Han er yrkesfaglærer og underviser på elektrolinjen. 
Tabell 1. Demografi

\begin{tabular}{|l|l|l|}
\hline Skole A, videregående & Skole B, videregående & Skole C, videregående \\
\hline Byskole ca. 1000 elever & Tettsted ca. 400 elever & Tettsted ca. 1000 elever \\
\hline Ole, 26 års erfaring & Bitte, 14 års erfaring & Knut, 16 års erfaring \\
Fag: Norsk, tysk & Fag: Spansk, samfunnsfag & Fag: Norsk \\
\hline Mari, 9 års erfaring & Tom, 15 års erfaring & Per, 27 års erfaring \\
Fag: Samfunnsfag, religion & Fag: Naturfag, matematikk & Fag: Elektrofag \\
\hline
\end{tabular}

\section{Metode}

\section{Forskningsinstrument}

Målet vårt var å få innsikt i lærernes opplevelse av handlingsrom og samtidig hvordan de selv syntes at de utnytter og har utnyttet dette handlingsrommet over tid. Metodene som er brukt er klasseromsobservasjon, semi-strukturerte intervjuer og story-line. De tre forfatterne gjennomførte datainnsamling for to lærere hver i den norske delen av studien. Denne metodologien gir muligheter for å gå i dybden på sammensatte problemstillinger (Merriam, 1998).

\section{Observasjon}

Vi skygget hver lærer gjennom én dag som inkluderte minimum fire undervisningstimer. I tillegg kom formelle og uformelle samtaler vi hadde med læreren samt notater fra møter som lærerne deltok i. Underveis ble det tatt feltnotater der vi særlig prøvde å notere oss hvordan lærerne utnyttet handlingsrommet sitt. Lærernes handlinger ble gjennom dette dokumentert, og observasjonene brukt som bakgrunn for å forstå og å snakke om deres praksis.

\section{Intervju}

Vi intervjuet lærerne i for- og etterkant av arbeidsdagen. De ble bedt om å fortelle hvordan de opplevde sin profesjonelle historie, praksis, motivasjon for å bli lærere og for å undervise. Fortelling kan mer enn spørsmål og svar gi rom for den subjektive erfaringen og gi tilgang til mer enn intervjueren ville kommet på å spørre om (Connelly \& Clandinin, 1990; Orland-Barak \& Maskit, 2011). Vi hadde en samtale med hver enkelt informant i forkant av intervjuet, blant annet for å forsikre oss om at vi hadde en mest mulig felles forståelse av begrepet profesjonelt handlingsrom. Vi ønsket også å få belyst hvordan de så på seg selv og sine muligheter og erfaringer som klasseledere, men også som deltakere i et kollegafellesskap som profesjonelle yrkesutøvere. Vi hadde fokus på her-og-nåsituasjonen så vel som deltakernes retrospektive blikk på erfart handlingsrom samt egen opplevelse av utnyttelsen av handlingsrommet. 


\section{Story-line}

For å belyse tidsperspektivet, ba vi lærerne om å tegne to tidslinjer, som uttrykte erfart og opplevd handlingsrom. Den horisontale aksen uttrykker antall år i jobb, den vertikale aksen grad av erfart og utnyttet handlingsrom. Lærerne ble bedt om å forklare «opp- og nedturene» som kom fram på tegningene. Også her prøvde vi å oppmuntre til fortellinger. Den vertikale aksen viser en skala 1-10 for omfang, mens den horisontale reflekterer lærernes profesjonelle tidslinje. Beijaard, Van Driel og Verloop (1999) viser hvordan story-line kan gi innsikt i læreres opplevelse av agency og handlingsrom over tid.

Lærerne tegnet linjene med blyant på et ark, noe som gjorde at de ble svært ulike i utforming. Gjengivelsene i artikkelen er basert på tegningene og må derfor sees på som visuell støtte for det som står i teksten, mer enn nøyaktige grafer.

\section{Data-analyse}

Intervjuene inkludert forklaringen på story-line ble tatt opp og transkribert. Basert på tolkning av dataene skrev hver av oss fortellingene om de to lærerne vi hadde skygget. Denne narrative analysen (Polkinghorne, 1995) basert på de sentrale elementene i dataene, ble utviklet i en moderasjonsprosess mellom forfatterne. Fortellingene ble sendt til lærerne for «member-check» for å sikre at historiene samsvarte med deres erfaringer samt at de var tilstrekkelig anonymiserte. I neste omgang foretok forfatterne i fellesskap en mer fortolkende analyse (Hatch, 2002). En slik tilnærming er karakterisert som forskerens beste forsøk på å skape mening i dataene gjennom å veksle mellom å se på del og helhet. Vi gjennomførte også en horisontal tilnærming der så på likheter og ulikheter mellom historiene og søkte å få en bedre forståelse av det profesjonelle handlingsrommet i materialet som helhet (Kelchtermans \& Ballet, 2002). I tillegg til narrativene, ble story-line-skjemaene analysert gjennom å se på opp- og nedturer som påvirket oppfatningen av det erfarte handlingsrommet og utnyttelsen av dette rommet.

\section{Etiske vurderinger}

Vi ser at utvalgsmåten gjennom ledelsen kan ha skapt et uheldig press på lærerne for å delta. Videre kan lærerne ha følt seg forpliktet til å være lojale og derfor ikke kunnet snakke helt fritt. Kritikken deltakerne kom med mot ledelsen, kan likevel tyde på at de følte seg frie til å svare det de ville. Samtidig var vi bevisste på at de skulle sikres anonymitet slik at de ikke var umiddelbart gjenkjennelige for ledelsen og at de var innforstått med hva de hadde akseptert å delta på. Gjennom «member-check» ønsket vi at de skulle sikres den nødvendige anonymiteten. Hensyn til anonymitet har medført at vi har sparsomt med sitater.

Studien er godkjent av Norges Samfunnsvitenskapelige Datatjeneste (NSD). 


\section{Metodologiske vurderinger}

Målet med artikkelen er å få en dypere forståelse av hvordan lærere selv opplever at de utnytter og har utnyttet sitt profesjonelle handlingsrom når de ser tilbake på yrkeskarrieren sin. For å komme så tett opptil målet som mulig, valgte vi å intervjue lærerne før og etter observasjonene i klasserommene. I intervjuet på forhånd fikk vi innsikt i lærernes planer og begrunnelser. I intervjuet etter observasjonen kunne vi stille utfyllende spørsmål til det vi hadde sett og opplevd sammen med lærerne i klasserommet. Intervju som metode vil alltid ha en viss bias knyttet til selvrapportering. For å balansere selvrapporteringen med supplerende data, gjennomførte vi skygging av lærerne. Vi brukte observasjonsdata som utgangspunkt i intervju nummer to, men observasjonsdataene var også en form for kontrolldata av selvrapporteringen. En tredje dimensjon av lærernes forståelse av sitt profesjonelle handlingsrom fikk vi ved bruk av story-line, som ikke bare viste dagens situasjon, men også åpnet for et tilbakeblikk på utviklingsmønsteret gjennom lærerkarrieren så langt. Begrepene erfart og utnyttet handlingsrom fungerte i samsvar med intensjonen som grunnlag for innhenting av empiri og som verktøy i analyseprosessen.

\section{Funn}

I det følgende vil vi beskrive lærernes opplevelse av det erfarte og det utnyttede handlingsrommet. Gjennom eksempler vil vi vise hvordan deres tolkninger kom til uttrykk. Det viste seg at flere lærere tegnet brudd på tidslinjene for å illustrere «opp- og nedturer». På tilsvarende måte vil vi vise hvordan viktige hendelser har påvirket lærernes opplevelse av handlingsrom.

\section{Opplevelse av handlingsrom}

Analysen viser at alle lærerne med unntak av én opplever å ha utnyttet et større handlingsrom enn de erfarte å ha. Tilsvarende har alle unntatt én tegnet en knekk på tidslinjen sin på grunn av ytre hendelser. Vi vil forklare årsaken til denne opplevelsen av brudd. 


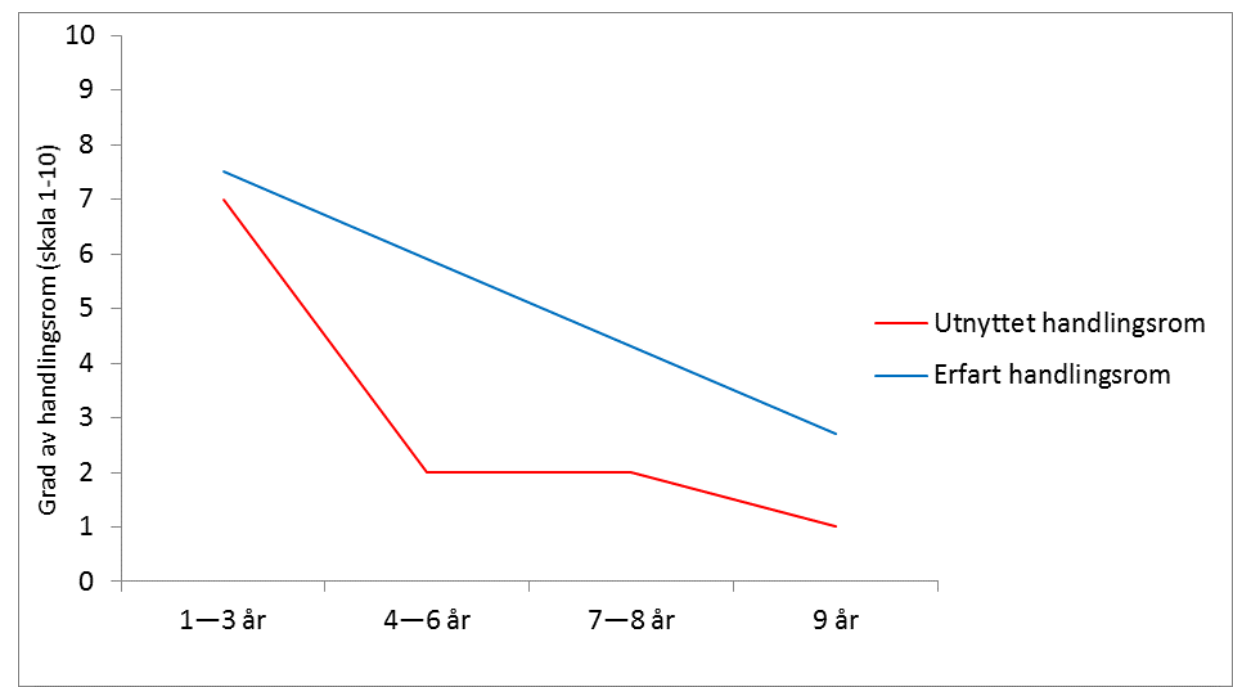

Figur 1. Maris story-line

Mari har minst yrkeserfaring av lærerne. Hun sier at det viktigste er at elevene trives. Hun er opprørt over en ny vurderingsordning som skal innføres på skolen. Hun har ikke behov for å gi elevene flere vurderinger, sier hun. Likevel er hun pliktoppfyllende og føler seg i en skvis mellom ledelsens forventninger og hensynet til elevene. Hun er også opprørt over at ledelsen mener elevene får for dårlige karakterer og at skolen derfor blir satt i et uheldig lys. Hun liker heller ikke å skrive anmerkninger i tråd med forventningene fra ledelsen. Likevel handler hun i tråd med ledelsens påbud. Gjennom ni år som lærer opplever hun at rommet hun har for å handle i tråd med egne mål blir stadig mindre: Det er mindre rom for å være selvstendig. Som vikarlærer på en kombinert barne- og ungdomsskole i starten av karrieren opplevde hun stor grad av frihet. På videregående skole blir mulighetene stadig mindre. Hun opplever å bli styrt av planer og regler kombinert med et stort arbeidspress. Etter at Mari fikk egne barn, har hun måttet begrense jobbingen sin:

På videregående skole er handlingsrommet blitt betraktelig mindre. Muligheten for å utforme egne undervisningsopplegg er fremdeles stor; det er ingen som forteller meg på hvilken måte en time skal foregå. Heldigvis så har jeg metodisk frihet! Men muligheten til å lage gode undervisningsopplegg er liten da hoveddelen av arbeidsdagen går med til andre ting enn «å snekre» sammen interessante undervisningsopplegg.

Sitatet fra Mari kan tolkes som at hun synes det erfarte handlingsrommet er blitt mindre, men også at det er vanskelig å utnytte det handlingsrommet hun tross alt har, fordi hun må ha fokus på andre ting enn undervisning. 


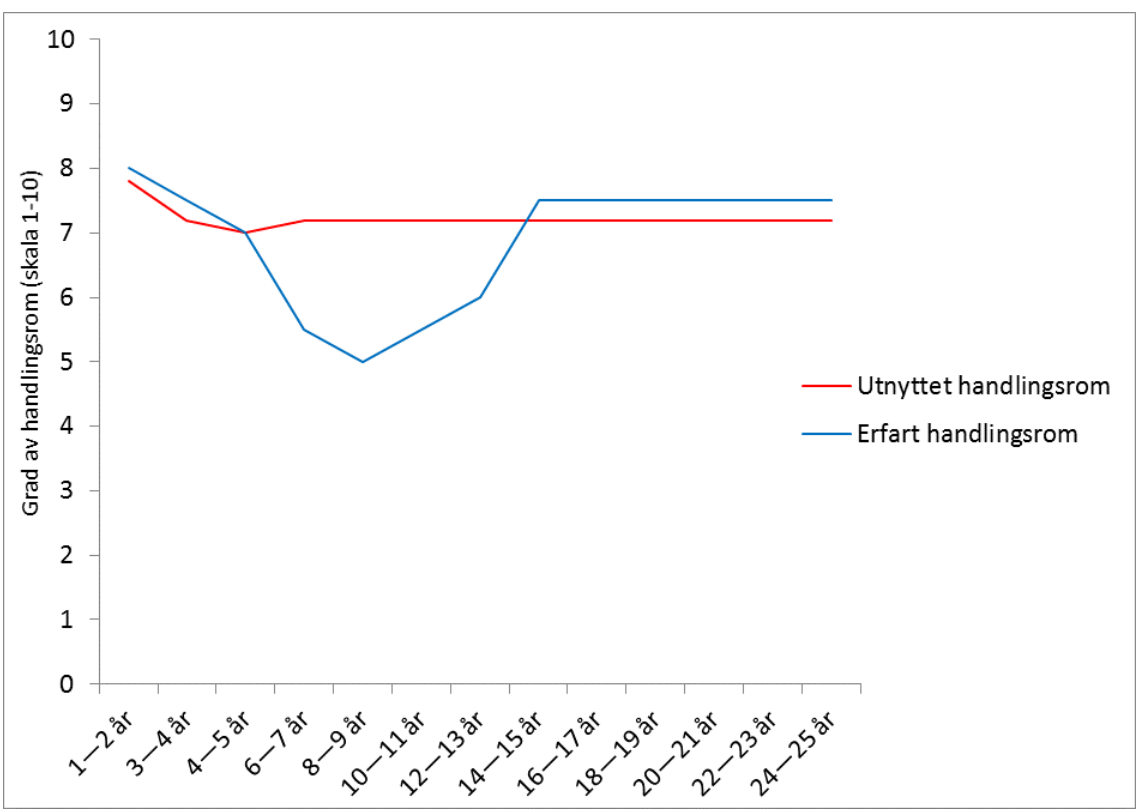

Figur 2. Oles story-line

Ole har 26 års erfaring. I dag opplever Ole at han stort sett gjør det samme som han alltid har gjort. Han er sikker i rollen som lærer og praktiserer yrket slik han mener er best for hans elever, ikke slik systemet sier han skal gjøre. Ole vet hva som må gjøres og hva han kan ta lettere på. Han gjennomfører jobben slik han selv ønsker det, samtidig som han ikke vil oppfattes som en unnasluntrer. Han nevner den samme vurderingsordningen som Mari. Ole har ikke tenkt å gjennomføre den. Han og elevene vet hvor de står i faget og har ikke behov for en ekstra vurdering. Ole synes synd på nye lærere som kommer inn i en organisasjon preget av krav og pålegg og tror de må gjøre alt. Han opplevde at det skjedde en endring i erfart handlingsrom da arbeidstidsordningen ble innført på slutten av 90-tallet. Det ble strenge krav til tilstedeværelse, men slik Ole så det, var det i stor grad opp til den enkelte rektor hvordan ordningen ble praktisert. Helt fra starten av yrkeskarrieren opplevde Ole å utnytte et stort handlingsrom, og viser til erfaringer som studentrepresentant på universitetet. Der var han vant til friske diskusjoner. Han opplevde at i den første delen av yrkesperioden utnyttet han mer frihet enn han egentlig hadde og at han var ulydig:

Handlingsrommet har variert, men jeg føler jeg har gjort det samme hele tiden. Det viktigste er den tiden du bruker til å forberede undervisning, gjennomføre undervisning og ikke minst håndtere rettebyrden som norsklærer. Hovedjobben min er relatert til undervisning og vurdering. Handlingsrommet har ikke endret seg noe særlig. Men det er større fokus fra ledelsen, fylket og Utdanningsdirektoratet på at det skal skje utviklingsarbeid på skolen, så du føler det litt sterkere i bakgrunnen hele tiden. Det stresser meg ikke. Jeg er ikke bevisst unnasluntrer, men jeg er veldig analytisk. Jeg tar meg visse friheter når det gjelder administrative gjøremål, men er flink til å analysere hva jeg må gjøre og ikke.

Ole utrykker at det er blitt et større ytre press, men at handlingsrommet likevel ikke er endret. Gjennom erfaring har han lært å håndtere det på sin egen måte. 


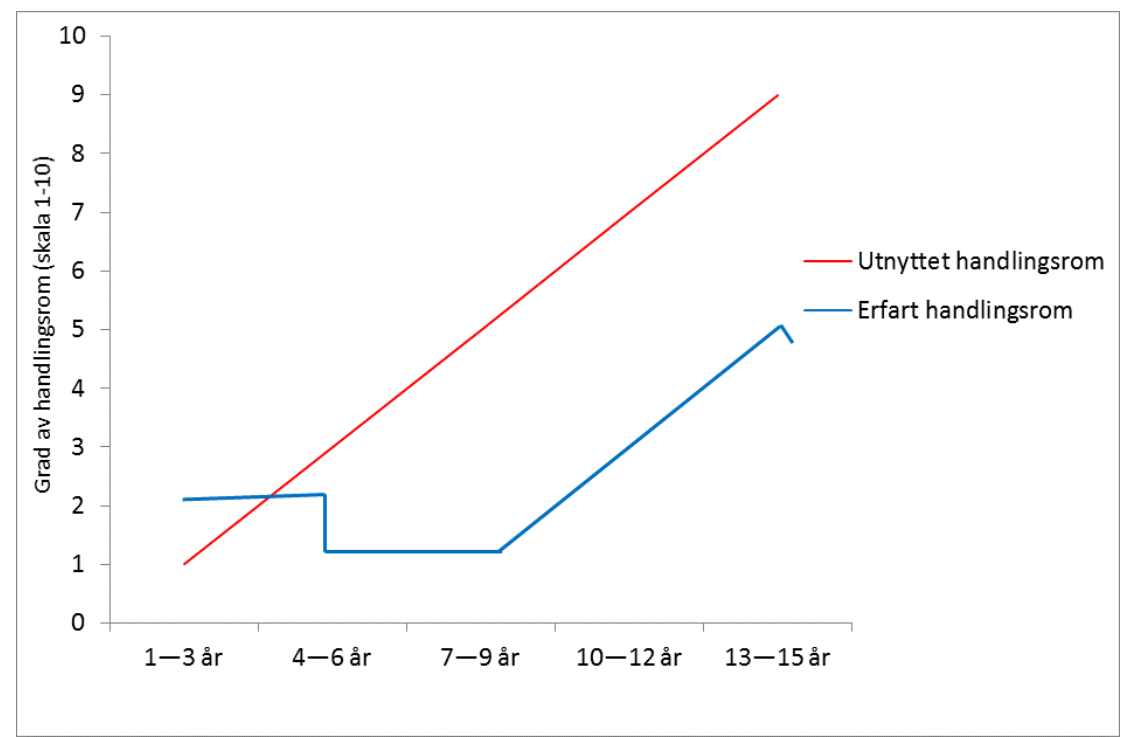

Figur 3. Bittes story-line

Bitte har lett for å si ja til oppgaver som ligger utenfor det hun er pålagt. Hun reiser for eksempel til Spania med elever på språkreise. Hun arrangerer skolevalg for alle elevene, og hun tar med elevene på internasjonale konkurranser. «Det er det som gjør jobben meningsfull,» sier Bitte. Handlingsrommet øker, samtidig som hun utnytter mulighetene bedre. Bittes story-line forteller om reduksjon i erfart handlingsrom etter de tre første årene. Hun var først ansatt på en liten barne- og ungdomsskole der ledelsen brydde seg lite om hva hun gjorde. Her opplevde at hun kunne følge sine egne mål. På den neste ungdomsskolen var rammene strengere. Her hadde hun opplevelsen av å bli styrt fra skoleledelsen og fra kommunen generelt. Der hun er nå, erfarer Bitte at hun får mer og mer handlingsrom, helt til hun tegner en liten knekk på tidslinjen sin. Årsaken er at spørsmålet fra ledelsen om å delta i dette forskningsprosjektet har fått henne til å reflektere over sin egen rolle i personalet. Kanskje er det fordi hun alltid sier ja til ekstra oppgaver at rektor plukket henne ut? Hun har spurt rektor om dette. Konklusjonen er at hun ønsker at flere skal dele på fellesoppgavene. Den siste knekken på kurven illustrerer bevisstgjøringsprosessen hennes. Noe av det hun har erfart som handlingsrom kan være oppgaver andre ville si nei til. I så fall spør hun seg selv om det kanskje handler mer om lydighet enn om å utnytte handlingsrom. 


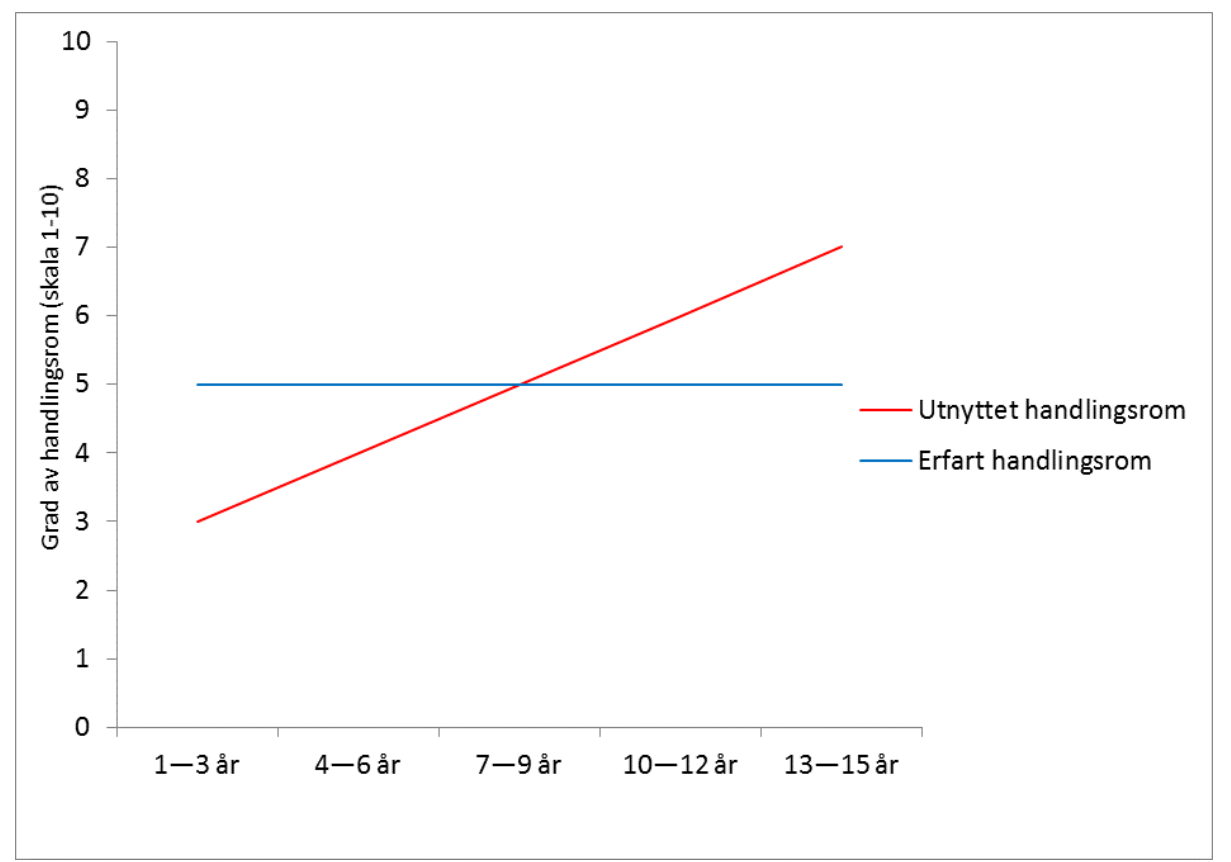

Figur 4. Toms story-line

Tom erfarer at han har stor frihet og tillit fra ledelsen. «Når vi lærere opplever at noe blir dyttet på oss, så minker gleden og viljen til å finne på ting på egen hånd,» sier Tom. Naturfagseksjonen har startet mange prosjekter som for eksempel «Den naturlige skolesekken» og «Lektor 2». Videre har de avtale med Naturfagsenteret om å bli energiskole. Alt er initiert fra naturfagseksjonen, og Tom er sentral. Ledelsen er informert, men ikke involvert. Som regel får de støtte og oppmuntring til å gå videre med prosjektene sine. Det erfarte handlingsrommet til Tom har en jevn kurve. Gjennom nettundervisningen der han startet sin yrkeskarriere og på den skolen han er nå, erfarer han at han har et stort handlingsrom og at dette har økt gjennom de 15 årene han har jobbet. Han blir stadig tryggere på å gjøre det han ønsker og ser hva han kan la være å gjøre.

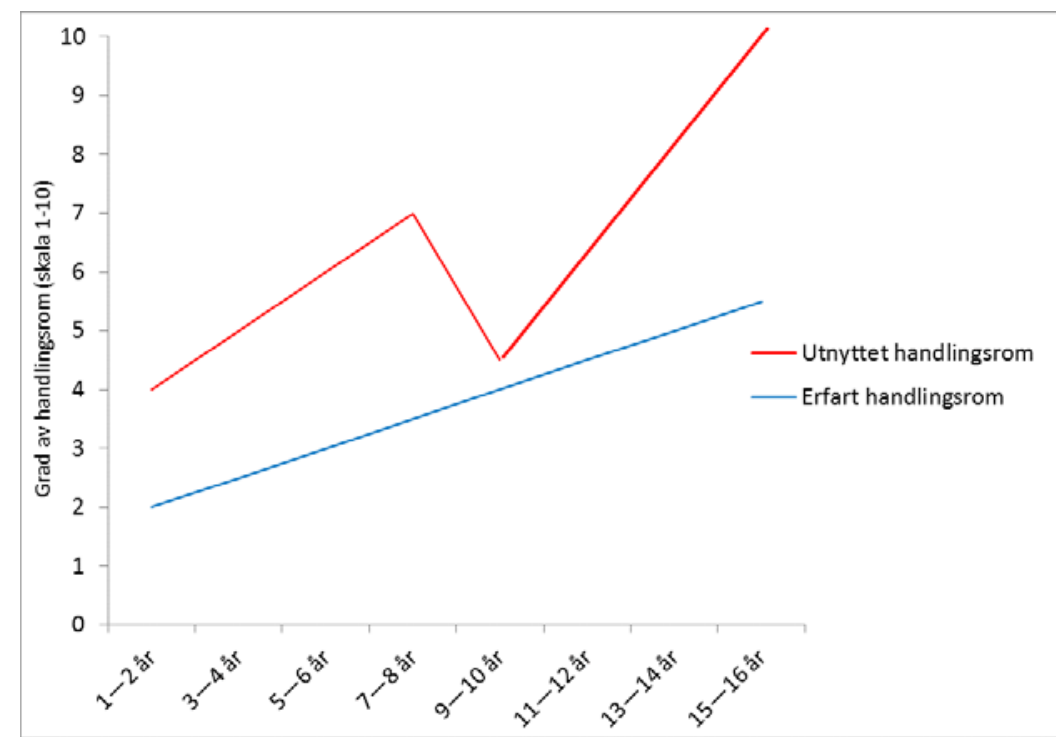

Figur 5. Knuts story-line 
Knut erfarer også at han har frihet til å handle profesjonelt. Det er langt til ledelsen på en skole med 1000 elever, sier han. Han synes det er en god skole der ingen forteller hva han skal gjøre. I starten av yrkeskarrieren var han lydig og gjorde det han ble fortalt, men gradvis opplevde han å bli tryggere og å få mer tro på seg selv. Etter hvert fikk han gode tilbakemeldinger fra elever og ledere og ble mer avslappet. Men etter 8 år fikk han en knekk. Han var lei og i ferd med å bli utbrent. «Det var vanskelig å være den læreren jeg ønsket å være ved siden av ansvaret jeg hadde overfor kona mi og tre barn,» sier Knut. Etterpå har opplevelsen av å ha et handlingsrom økt, slik at når kollegaene klager over direktiver fra myndighetene, erfarer ikke Knut at det påvirker hans muligheter for å følge egne mål. «Det er tross alt bare opp til meg selv. Det handler om å finne sin egen form innenfor systemet,» sier Knut.

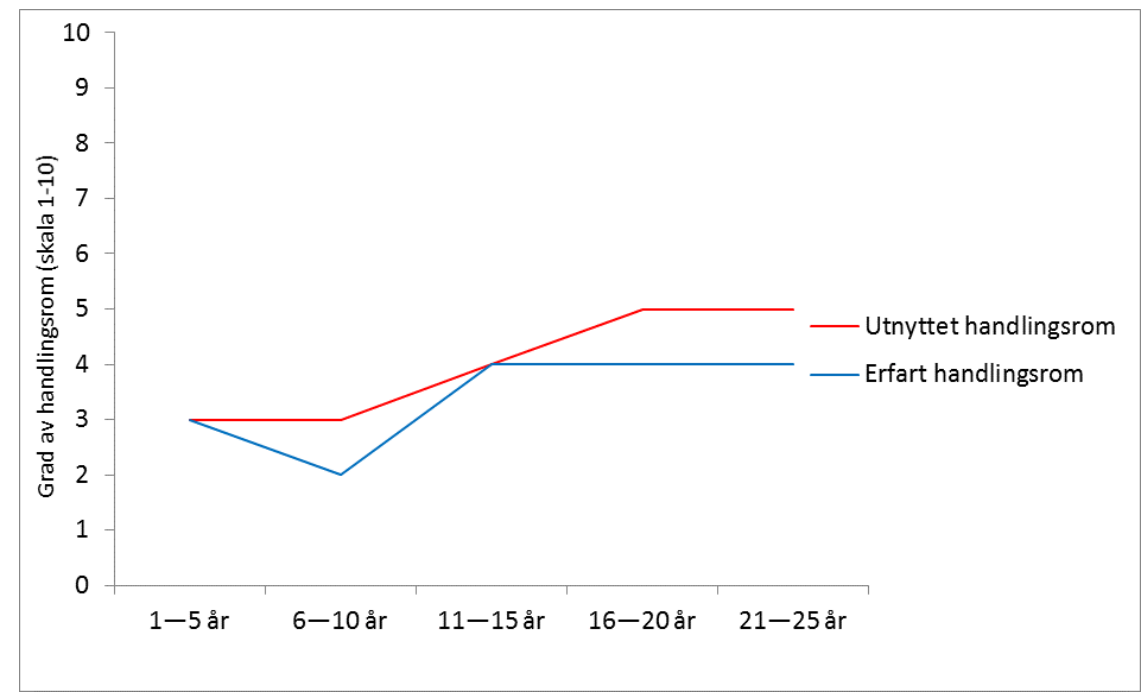

Figur 6. Pers story-line

Per er også en lærer som opplever å skape sitt eget profesjonelle rom der han kan nå sine egne mål. Undervisningen hans er basert på hans pedagogiske verdier og holdninger. Han lar seg ikke styre av skoledirektiver eller lærebøker. Per har alltid utnyttet et større handlingsrom enn han har erfart å ha. De nye arbeidstidsbestemmelsene som krevde at lærere skulle være på arbeidsplassen fra 08 til 16, utgjør en knekk på tidslinjen, men etter en kort periode opplevde Per at han kunne fortsette som før. «Min arbeidsdag har alltid vært og vil alltid være mer enn 8 timer selv om det ikke passer inn i et 8-16-skjema.» Det som også har bidratt til mindre erfart handlingsrom i perioder, er innføring av nye læreplaner og sammenslåing av yrkes- og allmennfaglinjene til én skole. Mulighetene for utnyttelse av handlingsrommet har stadig økt med erfaring. Pers opplevelse av gradvis økning i utnyttelse kan forklares med hans sterke tro på at undervisningen skal være til det beste for elevene på tross av press utenfra og ovenfra. Han opplever at han alltid har gjort dette, men at han er blitt tryggere etter hvert som han har fått mer erfaring. Det er viktig for Per at han har støtte i ledelsen. 
De fleste lærerne opplever at de har et stort profesjonelt handlingsrom, men de har ulik oppfatning av hvordan dette har endret seg over tid. De samme lærerne opplever også at de har utnyttet stadig mer handlingsrom gjennom yrkeslivet. Kurven har vært stigende gjennom karrieren. Dessuten opplever de fleste at de utnytter mer handlingsrom enn de erfarer å ha. Det gjelder for alle med unntak av Mari. Hennes linjer viser at utnyttet handlingsrom stadig minker. Erfart handlingsrom er for de andre relativt stabilt, men knekk på linjen og nedturer blir tegnet når det kommer pålegg og endringer fra ledelsen eller fra overordnede myndigheter. Etter en kort periode har de fleste lærerne likevel funnet sin egen måte å håndtere dette på, og kurvene har steget igjen for alle utenom Mari.

\section{Diskusjon}

Gjennom studien ønsket vi å få svar på hvordan lærere som av ledelsen vurderes til å utnytte en stor grad av handlingsrom, selv opplever at de bruker og har brukt sitt profesjonelle handlingsrom.

Over tid har det erfarte handlingsrommet, det vil si den subjektive opplevelsen av begrensninger og muligheter basert på rammefaktorer, enten vært relativt stabilt eller hatt en stigende kurve. For fem av de seks lærerne ligger grensen for det utnyttede handlingsrommet, lærernes forståelse av sitt profesjonelle handlingsrom, over det erfarte. Det betyr at det også i dag er mulig å være den læreren en ønsker å være. Her vil vi imidlertid understreke at vi har valgt positive case og at andre lærere med annen ledelse og andre ytre rammer kanskje ikke har samme opplevelse.

Alle lærerne, med unntak av Mari, oppgir å ha høy grad av erfart handlingsrom. Resultater fra den internasjonale studien som vår studie er en del av, viser at utnyttet så vel som erfart handlingsrom endrer seg over tid. Tidslinjene som ble tegnet, viste i de fleste tilfellene en stigning. Positiv respons fra elever, kollegaer og ledelse har gjort lærerne tryggere på å gjøre det de selv synes er rett. De blir sikrere i sin yrkesutøvelse og tør å ta mer selvstendige valg. Disse resultatene stemmer med Priestley m.fl. (2015) som viser at lærere gradvis utvider sitt handlingsrom gjennom aktivt å evaluere og tolke de kulturelle og strukturelle forholdene, og samtidig å handle i tråd med det de tror på som lærere (Oolbekkink-Marchand et al., 2017). I vår studie er Ole et typisk eksempel. Funnene fra den norske studien viser at alle lærerne har et sterkt engasjement rettet mot elevene og klassene sine, noe som også er i tråd med funnene i Israel og Nederland (Oolbekkink-Marchand et al., 2017), og i samsvar med andre studier (Ballet \& Kelchtermans, 2009; Biesta et al., 2015; Day, Stobart, Sammons \& Kington, 2006). Lærerne vet hva de vil gjøre i klasserommet. De har sine egne mål basert på sin egen pedagogiske overbevisning som de arbeider ut fra. Det er elevers læring som gir mening. Det er i relasjon til det de tror på, at 
de setter inn kreftene og definerer sine egne mål. Livet utenfor klasserommet får liten eller ingen oppmerksomhet. Det vil si at Bitte er opptatt av aktiviteter hun kan gjøre i andre fora enn klasserommet og Tom av prosjekter han og kollegaene kan delta i, men hensikten er at elevene skal få bedre undervisning.

Et annet funn dreier seg om viktige hendelser som har påvirket lærernes opplevelse av profesjonelt handlingsrom. I noen tilfeller handler det om det erfarte handlingsrommet, i andre om det utnyttede. Det er bare Tom som ikke oppgir at viktige hendelser har påvirket forståelsen av profesjonelt handlingsrom. Mari og Knut tegner en knekk på sin linje som illustrerer det utnyttede handlingsrommet. Begge oppgir at det er private forhold som har virket inn på jobben slik at de har hatt en opplevelse av å utnytte mindre handlingsrom. Bitte, Ole og Per tegner knekk på den erfarte tidslinjen og forteller om tolkning av ytre rammer som har påvirket dem. I Bittes tilfelle handler det om bytte av skole. Hennes opplevelse av det erfarte handlingsrommet er ulikt på de tre skolene hun har vært på i sin yrkeskarriere. Bitte har dessuten tegnet en interessant knekk på slutten av sin erfarte tidslinje. Spørsmålet om å delta i forskningsprosjektet fordi ledelsen vurderer henne til å være en av de lærerne som utnytter handlingsrommet, har fătt henne til å reflektere over sin rolle (Biesta et al., 2015). Følger hun egne mål, eller følger hun ledelsens mål og er en av de mest lydige lærerne? Ole og Per oppgir samme årsak for å tegne sin knekk på tolkningen av den erfarte tidslinjen, nemlig den nye arbeidstidsordningen for lærere i Norge på 90tallet. Begge har registrert endringen i det erfarte handlingsrommet, men har opplevelsen av at de etter hvert fortsatte som før i tråd med det de selv trodde på (Biesta et al., 2015). I alle tilfellene snakker vi om tolkninger av virkeligheten, enten det dreier seg om det utnyttede eller det erfarte handlingsrommet. Opplevelsen av handlingsrom blir påvirket av strukturelle, kulturelle og materielle faktorer som ligger utenfor individets kontroll (Erimbayer \& Mische, 1998; Biesta et al., 2015; Edwards, 2015) slik det skjer i disse tilfellene.

Mari skiller seg fra de andre informantene våre. Hun opplever å ha lite profesjonelt handlingsrom. Det erfarte handlingsrommet hennes er stadig minkende. Hun opplever at ytre forhold fører til at hun bruker mindre handlingsrom enn det hun erfarer at hun har, og at hun i minkende grad kan følge sine egne mål og verdier. Eksemplet angående ny vurderingsordning som kommer fram i både hennes og Oles narrativer, er interessant fordi det handler om samme utfordring som skjer på samme skole, men som de to responderer helt forskjellig på. Begge mener at tiltaket er overflødig og unødvendig med tanke på elevenes læring. Likevel handler de ulikt. Ole vil ignorere pålegget fra ledelsen, mens Mari vil gjennomføre det. Imants m.fl. (2013) viser at når lærere handler i klasserommet, omgjøres de ytre påleggene til egne mål slik at pålegg som gir muligheter for enkelte, kan virke hemmende på andre. Maris fortelling er interessant også ut fra andre perspektiver. Kurvene hun tegner går nedover. Mari har 9 års erfaring som lærer. Det betyr at hun startet sin karriere i en periode i norsk skolehistorie der målstyringsideologien hadde fått godt feste. Buchanan (2015) hevder at lærere 
som har startet sin yrkeskarriere i en tid preget av måloppnåelse og dokumentasjon lettere tilpasser seg andres mål enn lærere med lengre erfaring, noe som kan være tilfellet for Mari. Dette stemmer med annen forskning (Ellström et al., 2007; Hoekstra et al., 2009; Buchanan, 2015), og er interessant i lys av forskning som peker på økt press og tilpasning (Ball, 2008; Hargreaves \& Goodson, 2006; Skaalvik \& Skaalvik, 2010).

I den norske delen av studien viser alle fortellingene at ledelsen spiller en viktig rolle. Sammenligningen mellom de tre landene samsvarer også med tanke på at støtte fra ledelsen betyr mye for lærerne for å kunne utnytte sitt handlingsrom. Læreres verdier og holdninger, samt støtte fra ledelsen, er de faktorene som teller mest når det gjelder opplevelsen av å kunne utnytte handlingsrommet (Priestley et al., 2012). A og C er store skoler. På skole C virker ledelsen mer fraværende enn på skole A. På skole B er lærerne fornøyd med friheten de får til å utnytte handlingsrommet som de vil, men Bitte får gjennom deltakelse i forskningsprosjektet en erkjennelse av at hun kanskje har strukket seg for langt når det gjelder å si ja til oppgaver ledelsen ønsket å få utført. Ballet m.fl. (2006) peker på at i tillegg til ledelsen vil også samarbeidskulturer fungere som buffere mot ytre krav. I vår studie er informantene lite opptatt av kollegafellesskapet når de snakker om handlingsrommet sitt. Et unntak er Tom som forteller om naturfagsseksjonen som et team som utvikler nye ideer og planer sammen. Han forteller om gleden over å utvikle nye ideer sammen med kollegaer uten å bli stoppet av ledelsen.

Den internasjonale studien som denne studien er en del av, viser samsvar på mange områder, men skiller seg vesentlig på ett punkt; nesten alle de norske lærerne sier at de utnytter handlingsrommet i større grad enn de erfarer at de har dekning for. Lærere i Nederland og Israel opplever derimot at de handler innenfor og under grensene av det de opplever som erfart handlingsrom (Oolbekkink-Marchand et al., 2017). Selv om norske lærere opplever mange reformer, kontrolltiltak og minkende grad av tillit (Skaalvik \& Skaalvik, 2009, 2010), kan funn i denne studien tyde på at de i stor grad handler i tråd med sine egne mål og verdier, og at de får lov til det av ledelsen ved skolene. Det kommer klart fram at lærerne ønsker å handle innenfor rammene av det ledelsen aksepterer. Leithwood (2005) hevder at norsk lederskap generelt er lite hierarkisk. Norske lærere får mer frihet fra sine rektorer enn lærere i andre land, noe som kan bety at de er mindre redde for alvorlige represalier eller for å miste jobben om de følger egne mål som ikke er i samsvar med det erfarte handlingsrommet. Funnene er derfor i tråd med tidligere funn fra den norske konteksten som viser at skoleledere i liten grad er opptatt av å kontrollere eller detaljstyre det som skjer i klasserommene, og at lærere og ledere tar ansvar for ulike områder (Møller, 2004, 2006; Hovdelien, 2010).

Lærerne i studien har et stort engasjement knyttet til at elevene skal få så god undervisning som mulig. Særlig de erfarne lærerne omformer planer og rammevilkår til egne mål som de gjennomfører som ledere i klassene sine. Informa- 
sjonen om dette engasjementet er viktig for skoleledelse og politiske utdanningsmyndigheter dersom de virkelig ønsker å skape en bedre skole. Andre studier gjør lignende funn og konkluderer med at politiske myndigheter må ta lærere med på råd når nye planer skal lages. Dette er viktig for å utnytte lærernes kunnskaper og engasjement (Pyhältö et al., 2012; Biesta et al., 2015; Priestley et al., 2015). Å se læreres muligheter til å handle profesjonelt i samsvar med sine egne mål som et samspill mellom individuelle egenskaper, erfaringer og skolekontekst, kan hjelpe utdanningspolitikere til å forstå implikasjonene av politikken i praksisfeltet. Lærere sitter med nøkkelen til gjennomføring av skolereformer i praksis. Samtidig kan forståelsen av hva erfart og utnyttet handlingsrom er, hjelpe lærere til å reflektere over sin arbeidspraksis slik tilfellet var med Bitte. Lærerne er opptatt av skolekonteksten i den grad denne påvirker undervisningen. Våre informanter nevner i liten grad profesjonen og det utdanningspolitiske nivået. Ole er et lite unntak siden han fortsatt er involvert i fagforeningsarbeid som gjør at han har et blikk for utdanning i en større sammenheng, men i det daglige er det klasserommet lærerne er opptatt av.

\section{Implikasjoner}

Læreryrket er en profesjon som i stor grad blir styrt utenfra i en tid preget av krav til måloppnåelse, papirarbeid og byråkrati (Ball, 2008; Hargreaves \& Goodson, 2006; Skaalvik \& Skaalvik, 2010). Til tross for at utvalget er så lite at funnene ikke er generaliserbare, gir denne studien viktig informasjon om læreres egen erfaring med og utnyttelse av sitt profesjonelle handlingsrom. De erfarne lærerne gjør det de selv synes er riktig, mens den mindre erfarne tilpasser seg. Alle finner sine individuelle løsninger for å gjøre det best mulig for «sine» elever. For alle lærerne er det elevenes læring og elevenes beste som er målet med arbeidet. I tidligere studier er lærernes egne stemmer mindre tydelige, selv om det er den subjektive erfaringen til den enkelte lærer som er sentral med tanke på læreres motivasjon og gjennomføring av undervisning.

OECDs rapport om læreres profesjonelle utviklingsaktiviteter, Teaching and Learning International Survey (TALIS), viser at norske lærere samarbeider mye, men at dette samarbeidet i stor grad begrenser seg til praktiske løsninger og deling av planer. I rapporten kommer det fram at dype diskusjoner som fremmer profesjonell utvikling for den enkelte lærer eller for skoler som lærende organisasjoner, stort sett er fraværende (OECD, 2008, 2013; Helleve, 2017).

Individuelle og kollektive bevisstgjøringsprosesser med fokus på opplevelsen av det profesjonelle handlingsrommet kan være nøkkelen til utvikling av en skole som lykkes i å sette elevers læring i fokus. Implikasjoner av denne studien vil derfor være at lærere må involveres i overordnede diskusjoner om hva utdanning skal være. 


\section{Om forfatterne}

Ingrid Helleve er professor i pedagogikk ved Institutt for pedagogikk på Universitetet i Bergen. Hun er medlem av forskergruppen Undervisningsprofesjonalitet og pedagogikk. Helleves forskningsområder, der hun har nasjonale og internasjonale publikasjoner, er profesjonell utvikling for lærere og lærerutdannere, utfordringer og muligheter med digitale hjelpemidler i utdanning, samt interkulturell pedagogikk.

Institusjonstilknytning: Universitet i Bergen, Christiesgate 13, 5020 Bergen

E-post: Ingrid.helleve@uib.no

Marit Ulvik er professor i pedagogikk ved Institutt for pedagogikk på Universitetet i Bergen. Hun er leder for forskningsgruppen Undervisningsprofesjonalitet og pedagogikk som er opptatt av menneskers læring, utvikling og danning innenfor skole og høyere utdanning. Hun har lang erfaring fra grunnskolen, og forskningsinteressene er i hovedsak rettet mot profesjonell utvikling og danning. Institusjonstilknytning: Universitet i Bergen, Christiesgate 13, 5020 Bergen E-post: Marit.ulvik@uib.no

Kari Smith er professor i pedagogikk ved Institutt for lærerutdanning, NTNU. Hun er daglig leder av den nasjonale forskerskolen i lærerutdanning, NAFOL. Smith har publisert internasjonalt og nasjonalt om vurdering, profesjonell utvikling og lærerutdanning. Hun er leder for The International Forum for Teacher Educators' Professional Development (InFo-TED).

Institusjonstilknytning: Institutt for lærerutdanning (ILU), NTNU, Jonsvannsveien 82, 7491 Trondheim

E-post: Kari.smith@ntnu.no

\section{Referanser}

Ball, S. J. (2008). The education debate. Bristol, UK: The Policy Press.

Ballet, K. \& Kelchtermans, G. (2009). Struggling with workload: Primary teachers' experience of intensification. Teaching and Teacher Education, 25(8), 1150-1157.

Ballet, K., Kelchtermans, G. \& Loughran, J. (2006). Beyond intensification towards a scholarship of practice: analysing changes in teachers' work lives. Teachers and Teaching: theory and practice, 12(2), 209-229. DOI: http://dx.doi.org/10.1080/13450600500467415

Bandura, A. (2006). Toward a psychology of human agency. Perspectives on psychological science, 1(2), 164-180). DOI: http://dx.doi.org/10.1111/j.1745-6916.2006.00011.x

Beijaard, D., Van Driel, J. \& Verloop, N. (1999). Evaluation of story-line methodology in research on teachers' practical knowledge. Studies in Educational Evaluation, 25, 47-62.

Berg, G. \& Wallin, E. (1983). Skolan i ett utvecklingsperspektiv. Lund: Studentlitteratur.

Biesta, G. \& Tedder, M. (2007). Agency and learning in life-course: Towards an ecological perspective. Studies in Education of Adults, 39, 132-149. 
Biesta, G., Priestley, M. \& Robinson, S. (2015). The role of beliefs in teachers'agency. Teachers and Teaching: theory and practice, 21(6), 624-640.

Buchanan, R. (2015). Teacher identity and agency in an era of accountability. Teachers and Teaching: theory and practice, 21(6), 700-719. DOI: http://dx.doi.org/10.1080/13540602.2015.1044329

Connelly, F. M. \& Clandinin, D. J. (1990). Stories of Experience and Narrative Inquiry. Educational Researcher, 19(5), 12-14. DOI: http://dx.doi.org/10.2307/1176100

Day, C., Stobart, G., Sammons, P. \& Kington, A. (2006). Variations in the work and lives of teachers: relative and relational effectiveness. Teacher and Teaching; theory and practice, 12(2), 169-192.

Edwards, A. (2015). Recognising and realising teachers' professional agency. Teachers and Teaching: theory and practice, 21(6), 779-784. DOI: http://dx.doi.org/10.1080/13540602.2015.1044333

Ellström, E., Ekholm, B. \& Ellström, P.-E. (2007). Two types of learning environment. Enabling and constraining a study of care work. Journal of Workplace Learning, 20(2), 84-97.

Erimbayer, M. \& Mische, A. (1998). What is agency? American Journal of Sociology, 103, 962-102. DOI: http://dx.doi.org/10.1086/231294

Grudnoff, L. (2012). All's well? New Zealand beginning teachers' experience of induction provision in their first six months in school. Professional Development in Education, 38(3), 471-485.

Hammerness, K, Darling-Hammond, L. \& Bransford, J. (2005). How teachers learn and develop. I L. Darling-Hammond \& J. Bransford (red.), Preparing Teachers for a Changing World: What teachers should learn and be able to do (s. 358-389). New York: Jossey-Bass.

Hargreaves, A. \& Goodson, I. (2006). Educational change over time? The sustainability and nonsustainability of three decades of secondary school change and continuity. Educational Administration Quarterly, 42(1), 3-41.

Hatch, J. A. (2002). Doing Qualitative Research in Education Settings. New York: State University of New York University Press.

Helleve, I. (2017). Formally educated mentors in Norway. Possibilities and challenges in mentors' support of colleagues’ professional development. Nordvei, 2(1), 30-44.

Hoekstra, A., Korthagen, F., Brekelmans, M., Beijaard, M. \& Imants, J. (2009). Experienced teachers' informal workplace learning and perceptions of workplace conditions. Journal of Workplace Learning, 21(4), 276-298.

Hovdelien, O. (2010). «Det er ingen av mine lærere som forkynner...». Grunnskolerektorers forståelse av egen rolle og eget handlingsrom i forbindelse med religions- og livssynsundervisningen. Prismet, 61(3), 77-86.

Imants, J., Wubbels, T. \& Vermunt, J. D. (2013). Teachers’ enactments of workplace conditions and their beliefs and attitudes toward reform. Vocations and Learning, 6(3), 323-346.

Jeppesen, S., Kelder, K. \& Ottesen, E. (2016). Rektors handlingsrom mellom skolens rammer og forventninger. Norsk Pedagogisk Tidsskrift, 2, 143-154.

Kelchtermans, G. \& Ballet, K. (2002). The micropolitics of teacher education. A narrative biographical study on teacher socialization. Teaching and Teacher Education, 18,105120. DOI: http://dx.doi.org/10.1016/s0742-051x(01)00053-1

Leithwood, K. (2005). Understanding successful principal leadership: Progress on a broken front. Journal of Educational Administration, 43(6), 619-629.

Merriam, S. B. (1998). Qualitative Research and Case Study Applications in Education. San Fransisco: Jossey-Bass Publishers. 
Møller, J. (2006). Nyere forskning om skoleledelse i gode skoler. Norsk Pedagogisk tidsskrift, 90(2), 96-108.

Møller, J. (2004). Lederidentiteter i skolen. Posisjonering, forhandlinger og tilhørighet. Oslo: Universitetsforlaget.

OECD (2008). Creating Effective Teaching and Learning Environments: First Results from TALIS (Teaching And Learning International Survey). Nedlastet fra: http://www.oecd.org/document/54/0,3746,en_2649_39263231_42980662_1_1_1_1,00.ht $\underline{\mathrm{ml}}$

OECD (2013). High-Quality Teacher Professional Development and Classroom Teaching Practices: Evidence from TALIS 2013. Nedlastet fra: https://www.oecd.org/edu/school/talis.htm

Oolbekkink-Marchand, H. W., Hadar, L., Smith, K., Helleve, I. \& Ulvik, M. (2017). Teachers' perceived professional space and their agency. Teaching and Teacher Education, 62, 37-46.

Orland-Barak, L. \& Maskit, D. (2011). Novices 'in story’: what first-year teachers' narratives reveal about the shady corners of teaching. Teachers and Teaching: theory and practice, 17(4), 435-450. DOI: http://dx.doi.org/10.1080/13540602.2011.580520

Polkinghorne, D. E. (1995). Narrative configuration in qualitative analysis. International Journal of Qualitative Studies in Education, 8(1), 5-23. DOI: http://dx.doi.org/10.1080/0951839950080103

Priestley, M., Edwards, R. \& Priestley, A. (2012). Teacher Agency in Curriculum Making: Agents of Change and Spaces for Manoeuvre. Curriculum Inquiry, 42(2), 191-214. DOI: http://dx.doi.org/10.1111/j.1467-873x.2012.00588.x

Priestley, M., Biesta, G., Phillippou, S. \& Robinson, S. (2015). The teacher and the curriculum: exploring teacher agency. I D. Wyse, L. Hayward \& J. Pandya (red.), The SAGE Handbook of Curriculum Pedagogy and Assessment (s. 187-201). London: SAGE.

Pyhältö, K., Pietarinen, J. \& Soini, T. (2012). Do comprehensive school teachers perceive themselves as active professional agents in school reforms? Journal of Educational Change, 13(1), 95-116. DOI: http://dx.doi.org/10.1007/s10833-011-9171-0

Rippon, J. \& Martin, M. (2006). Call me teacher: the quest of new teachers. Teachers and Teaching: theory and practice, 12(3), 305-324.

Skaalvik, E. M. \& Skaalvik, S. (2009). Does school context matter? Relations with teacher burnout and job satisfaction. Teaching and Teacher Education, 25(3), 518-524.

Skaalvik, E. M. \& Skaalvik, S. (2010). Teacher self-efficacy and teacher burnout. A study of relations. Teaching and Teacher Education, 26(4), 1059-1069.

Toom, A., Pyhältö, K. \& O’Connell Rust, F. (2015). Teachers’ professional agency in contradictory times. Teachers and Teaching: Theory and Practice, 21(6), 615-623.

Utdanningsforbundet (2014). Styring og maktforskyvning i utdanningssektoren. Temanotat 6/2014. Nedlastet fra: https://www.utdanningsforbundet.no/varpolitikk/kunnskapsgrunnlag/publikasjoner/2014/styring-og-maktforskyvning-iutdanningssektoren/

Van der Heijden, H. R. M. A., Geldens, J. J. M., Beijaard, D. \& Popeijus, H. L. (2015). Characteristics of teachers as change agents. Teachers and Teaching: Theory and Practice, 21(6), 681-699. 